\title{
FENCES, CONSERVATION, AND TOURISM: A HISTORY OF THE Jacskon Hole Wildlife PARK
}

\author{
MiCHAEL WEEKS $\uparrow$ HISTORY DEPARTMENT $\uparrow$ UNIVERSITY OF COLORADO $\uparrow$ BOULDER
}

On a pleasant July day in 1948, a small crowd congregated in rows upon rustic logs on the edge of a broad meadow in Jackson Hole, Wyoming. Beyond the meadow to the west, they spied glimpses of the Snake River through aspen, fir, and pine trees. On the horizon, Mt. Moran loomed, framed by a vast expanse of azure sky. The crowd's eyes however were not fixed upon the distant view, but on the small makeshift podium placed at the foot of the benches, and on the seven dignitaries who were scheduled to speak that day (Figure 1). They had come to dedicate the Jackson Hole Wildlife Park (JHWP). Conceived in 1945, the Park would provide controlled habitat for a host of primarily big game animals from the region, affording tourists the opportunity for education and close-up viewing of native mammals.

Laurance Rockefeller was the most anticipated speaker. He was the grandson of John D. Rockefeller, America's preeminent oil tycoon, and son of John D. Rockefeller Jr., (Figure 2) who had purchased the lands on which the JHWP now sat. Laurance oversaw the administration of those lands. In expounding on the Park's purpose, Laurance argued that tourism and conservation were linked, stating that visitors would "see wildlife..., learn to identify the various animals and birds, to appreciate them, to understand the problems involved in their protection, the need for preserving forests, safeguarding watersheds, saving the wilderness - in effect, the people will see what they are asked to conserve." In addition, Rockefeller argued out that the Wildlife Park

1 Quotes taken from Laurance S. Rockefeller, "Remarks Made at the Opening Ceremonies of the Jackson Hole Wildlife Park, Monday July 19, 1948," in Grand Teton National Park: Jackson Hole Wildlife Park, Historic Records Collection (Hereafter referred to as Wildlife Park Collection), Box 5, Series 13, Folder 1; The literature which connects tourism and conservation in American History is would promote equality and the local economy through affording greater access to wildlife for all visitors, while also bringing in tourist dollars. In short, Laurance presented a JHWP which offered universal benefits for nature - human and non-human. ${ }^{1}$

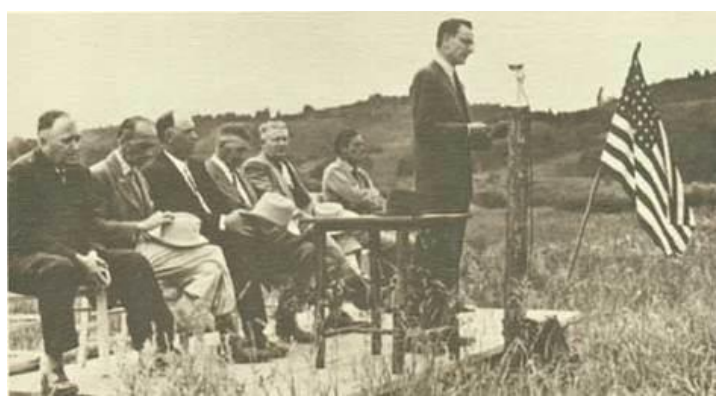

Figure 1. Laurance Rockefeller speaks at the opening ceremony. Reprinted, by permission, from Grand Teton National Park: Jackson Hole Wildlife Park, Historic Records Collection"

Though Rockefeller's speech presented an uncomplicated picture of Wildlife Park benefits, events which preceded its establishment demonstrated that tourism, conservation, and economics were far more complex and contested than Laurance revealed. In 1927, John D. Rockefeller Jr. formed the Snake River Land Company, and used it to secretly buy cattle ranches in Jackson Hole, hoping to eventually turn those lands over to the federal government for the establishment of a national park. The land which

deep. For an argument which largely praises that connection see Robert Righter, Crucible for Conservation: The Creation of Grand Teton National Park (Boulder: Colorado Associated University Press, 1982). For a more critical appraisal, see Richard West Sellars, Preserving Nature in the National Parks (New Haven: Yale University Press, 1997). 
would become the JHWP was purchased as a part of this scheme.

Rockefeller did not act alone however. His philanthropy had its origins in the minds of several local conservationists, including dude rancher Struthers Burt and Yellowstone Park Director Horace Albright both of whom hoped to preserve Jackson Hole for wildlife and tourism. To ensure that speculation would not drive up the costs of the land, Rockefeller employed Kenneth Chorley, a confidant who would eventually direct most of Rockefeller's conservation efforts, to gain executive approval for the withdrawal of nearly all of the remaining lands in Jackson Hole which had been open for settlement. Land use was further restricted when on February 26, 1929 the 96,000 acre Grand Teton National Park was created, setting aside the Teton Peaks and several alpine lakes at their base from development. The net effect for locals of so much land withdrawal was a loss of agency, as population growth in the region from this point on would be almost entirely confined to the town of Jackson, at the southern end of the valley, and to lands nearby which were already owned by cattle and dude ranchers. By 1930, when Rockefeller's plans for Jackson Hole were revealed, local opposition to the NPS - to Albright and Rockefeller in particular - and distrust of non-locals had intensified. ${ }^{2}$

Though conflicted ideas regarding the value and management of Jackson Hole did not die out during the 1930s, it was the presidential proclamation of Jackson Hole National Monument (JHNM) on March 5, 1943 that stoked the greatest controversy during the first half of the twentieth century. The Monument encompassed almost all lands in Jackson Hole - including future Wildlife Park lands - aside from the town of Jackson and the nearby Elk Refuge, and was managed by the federal government. Local ranchers howled out of fear that they would lose grazing rights and that their land would be devalued. Teton County and the state of Wyoming cried foul owing to the potential loss of tax base from the withdrawn lands, and from the perception that states' rights were being trampled by the federal takeover of lands which had previously been administered by the

${ }^{2}$ Righter, 43-65; Horace M. Alright, Director of National Park Service to Wilford Neilson, Editor, Jackson Hole Courier, Washington, D.C., 5 April 1933, in Mr. John D. Rockefeller Jr. 's Proposed Gift of Land for the National Park System in Wyoming, unpublished typescript obtained from the University of Wyoming at Laramie, 1-41.

3 Conclusions are drawn from issues of the Jackson's Hole Courier, March -June, 1943, with more dense analysis of these articles occurring later in this paper. The arguments for the Wyoming congressional delegation state. Wyoming's congressional delegation unanimously denounced the JHNM, twice attempting and failing to abolish it. ${ }^{3}$

The Monument also became a cause célèbre for conservationists. Dude ranchers such as Struthers Burt and Charles Cornell Moore, as well as former NPS Director Horace Albright, regarded the JHNM as a fulfillment of their plan for Jackson Hole as hatched twenty years earlier. Meanwhile, writers for a diverse array of progressive publications promoted nationwide embrace of the JHNM, believing that it would protect the area from commercial exploitation, provide a vast natural playground for tourists, and promote the preservation of the landscape and its wildlife. ${ }^{4}$ Thus, in October, 1945, when the Jackson Hole Game Park (the original name for the JHWP) was launched, the use of its lands was still contested, and those responsible for the Park's creation continued to draw both ire and praise.

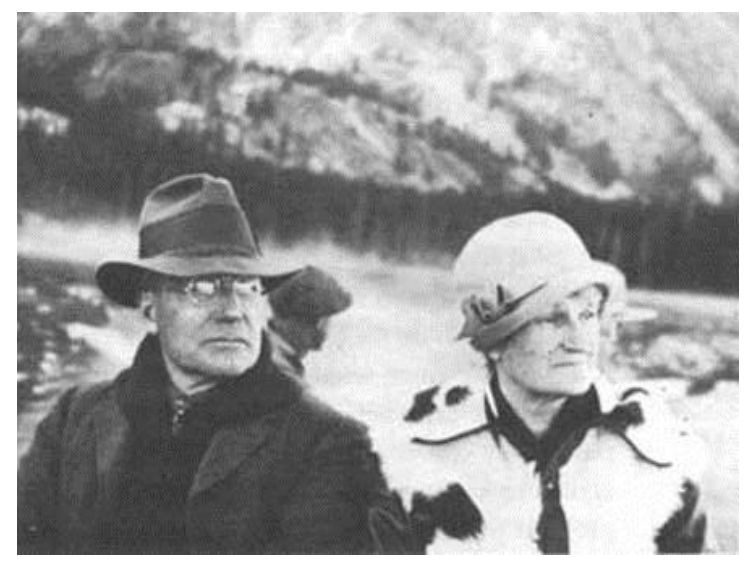

Figure 2. John D. Rockefeller Jr. and his wife Abby at Jenny Lake, 1931. Reprinted, by permission, from Grand Teton National Park: Jackson Hole Wildlife Park, Historic Records Collection"

Support and opposition to the new Park unveiled a somewhat new cast of characters and an evolving set of issues. Laurance Rockefeller, Horace Albright, and Struthers Burt were joined in their backing by Wyoming governor Lester Hunt, and the state's Fish and Game, and Highway Commissions.

are primarily drawn from Congress, House, Committee on Public Lands, "To Abolish the Jackson Hole National Monument, Wyo.: Hearings before the Subcommittee on Public Lands of the Committee on Public Lands," $80^{\text {th }}$ Cong., $1^{\text {st }}$ Session, 14-18 April, 1947, H.R. 1330.

${ }^{4}$ Examples of these publications include Bernard DeVoto, "The West Against Itself," Harper's Magazine, January 1947, 1-13, and Struthers Burt, "The Jackson Hole Plan,” Outdoor America, November - December, 1944. 
Together, they embodied a cautiously optimistic new coalition of local and state tourism boosters. In 1943, when the Jackson Hole National Monument was created, both governor Hunt and the Wyoming Department of Fish and Game (WDFG) strenuously opposed, arguing that it would reduce tax revenues, hurt the cattle industry, and limit hunting opportunities for locals. Though they still resented federal authority and the National Park Service (NPS) in particular, locals and Wyoming state official had rapidly come to embrace the growing hordes of visitors who poured into Jackson Hole to ski, visit the Monument, and gawk at wildlife. It turned out that wildlife had much greater economic value for viewing than hunting. Moreover, outsiders such as Rockefeller and Albright may not have become overnight celebrities, but projects such as the Game Park could potentially be molded to suit new aims. ${ }^{5}$

Fairfield Osborn was another figure who played a prominent role in the founding and molding of the new Park. As president of the New York Zoological Society, Osborn was primarily interested in the fauna of the JHWP. He argued that the Wildlife Park re-created a natural environment that contributed to public education, stating that if nature was threatened, it should be brought to the people. Thus, the Wildlife Park and its attached research station were desirable since they allowed the public to get a glimpse en masse of animals which few would encounter in their natural habitat. Further, Osborn paid special attention to obscuring any fencing from the public, even arguing that the large mammals would scarcely be aware of their confinement. Osborn believed that the success of conservation required mass education, and the Wildlife Park would be a tool for this enlightenment. ${ }^{6}$

Ironically, the most principled opposition to the Wildlife Park came from friend and fellow

5 My conclusions come primarily from analyses of the Jackson's Hole Courier from 19431947. See especially “Governor Lester C. Hunt States Views on Proposed Jackson Hole Game Park," 31 January 1946, 1.

6 An excellent summary of Osborn's philosophy for the Wildlife Park is provided in "When Nature is the Zoo: Vision and Power in the Art and Science of Natural History" Osiris 11 (1996): 117143. On Osborn's advocacy of the role of humans in nature, see Fairfield Osborn, Our Plundered Planet (Boston: Little, Brown and Company, 1948), 194-201; On the role of a fence in the Wildlife Park, see Fairfield Osborn to Carl Jorgenson, 22 January 1949, Charles Cornell Moore Collection, Conservation conservationist, Olaus Murie. A wildlife biologist, former director of the Jackson Hole Elk Refuge, and soon to be president of the Wilderness Society, Murie also sat on the board of the Jackson Hole Preserve, Inc., which managed and directed the use of Rockefeller lands in Jackson Hole. In November, 1945, Murie resigned his position in protest, calling the Wildlife Park a 'roadside zoo.' In a 1946 article for National Parks Magazine, Murie opined that fenced wildlife could set a precedent for similar attractions in national parks. Though the Wildlife Park was placed on Rockefeller lands, John D. Rockefeller Jr. had always intended that they be used in an expanded Grand Teton National Park, an eventuality that might force the NPS to accept the JHWP within its borders. Additionally, Murie argued that the Wildlife Park was representative of a general trend toward laziness in the American approach to the outdoors. Calling it "recreation on a platter," he argued that the JHWP would enable thousands of tourists to observe magnificent animals while hardly exiting their vehicle. Further, he posited that this would cheapen the experience of encountering animals in the wild since wildlife could be observed behind concealed fences by simply driving into the valley. For Murie, the Wildlife Park commercialized the wonder of nature and packaged it for a mass audience. In the process, the authenticity of a direct encounter with wildlife was lost. ${ }^{7}$

The issues involved in the creation of the Jackson Hole Game Park help to illuminate many of the larger conservation issues of the period. The proliferation of national parks and other public lands, the development of the automobile, and an increase in leisure time during the first half of the twentieth century enabled more Americans to visit places such as Jackson Hole. Conservationists, most of whom were extra-local and did not rely on the land directly for their livelihood, generally viewed tourists as

Collection, Denver Public Library (Hereafter referred to as Moore Collection), Box 1, File Folder 114.

${ }^{7}$ Olaus Murie to Struthers Burt, 5 December 1945, Olaus Murie Collection, Conservation Collection, Denver Public Library (Hereafter referred to as Murie Collection), Box 2, File Folder 43; Olaus Murie, "Fenced Wildlife for Jackson Hole," National Parks Magazine, January-March 1946, 8-11; Gregg Mitman, Reel Nature: America's Romance with Wildlife on Film (Cambridge: Harvard University Press, 1999), 89; On the Wilderness Society's opposition to roadside nature, see Paul Sutter, Driven Wild: How the Fight Against Automobiles Launched the Modern Wilderness Movement (Seattle: University of Washington Press, 2002), 23-53. 
natural allies in protecting the land and its flora and fauna. Broadly speaking, Laurance Rockefeller, Struthers Burt, Horace Albright, and Fairfield Osborn fell into that camp. However, Olaus Murie represented a growing number of conservationists who, in the 1940s, questioned such an anthropocentric approach. He argued that easy human access to nature only served to fragment critical habitat, endangering the very resources conservationists sought to protect. In many ways, this debate over what constituted effective conservation would be central to the saga of the Wildlife Park from 1945-1953.

In the two-and-one-half years between the approval of the Park in 1945, and its opening in 1948, the Wildlife Park Trustees, which included Rockefeller, Osborn, representatives of WDFG, and a few interested Jackson Hole locals, busied themselves developing its infrastructure, and shoring up public support. As part of this preparation, they enlisted a group of visiting college students in 1947 to survey seventy-five locals on their knowledge of the Wildlife Park, their support for its mission, and their feelings about those who directed its operations. A brief overview of survey results revealed that all but one of the respondents was familiar with the JHWP and that the vast majority supported it. Responses to multiple queries on tourism showed that, depending on the question, anywhere from $77 \%-100 \%$ of those surveyed supported visitors to Jackson Hole. Moreover, a consistently sizable majority supported conservation, the display of big game animals for the public, and the use of fences to corral them within the confines of the Wildlife Park. The survey made clear however that many locals still distrusted the federal government, as a far larger percentage responded that the state of Wyoming was more capable of managing the JHWP than the federal government. ${ }^{8}$

Additional moves broadened the scope of the Park, and garnered increased support. One of the first moves was to change the original moniker "Jackson Hole Game Park," to "Jackson Hole Wildlife Park."(Figure 3). Though casual observers could not miss the fact that the park prioritized big game animals, it was also clear that the term "game" implied hunting, an activity that repelled some tourists and suggested that the representative species of the Park existed primarily as sport and as food. In seeking to

${ }^{8}$ CR Carpenter and Hollis Farnum, "Information Schedule on Jackson Hole Region: A Project: The Jackson Hole Summer Research Program", Unpublished Typescript in Wildlife Park Collection, Box 4, Series 6, Folder 1. attract a broad array of tourists, Wildlife Park trustees sought a different kind of consumption. In 1947 , trustees made a more substantive change, when it decided to include a research station as part of the Wildlife Park. Eventually this station would provide opportunities for biologists to carry out studies of area wildlife and their habitat. Though the inclusion of the research station was promoted by trustees such as Osborn, it was clear that it contained political motivations as well. Several conservation organizations withheld their endorsement of the Wildlife Park until 1947. Some of them, most notably the Izaak Walton League and the American Society of Mammalogists, offered the Park their support once they learned that research would be included in its mission. It turned out that, for some conservationists, the unsavory and artificial aspects of enclosed wildlife were trumped by opportunities for scientific research. ${ }^{9}$

In preparation for opening in 1948, several practical matters needed to be addressed before tourists could visit the Wildlife Park. Of the 1,500 acres in the park, 400 of them were to be fenced for permanently enclosing large mammals. James Simon, director of the JHWP in 1947 reported approximate "stocking" numbers: 20 antelope, 20 buffalo, 10 elk, 6 moose calves, 10 mule deer, and 10 white-tailed deer. Buffalo were to be acquired from Yellowstone National Park, moose calves as well as elk were to be captured by Simon and his staff, and the remainder of the animals were to be procured from WDFG. The cost of labor, capture, and transport of this massive haul of fauna was just over $\$ 3,000$. Of course, these mammals were unaware that their mobility was now limited by contract. Consequently, fences and cattleguards were constructed to secure the arrangement. The initial enclosure for the 400 acres required five miles of fencing that would be eight feet high. In addition, cattleguards were to be placed across major roads coursing through the park. The combined material costs of the cattleguards and fencing came to over $\$ 27,000$. This infrastructure would prove to be a source of ongoing tension addressed later in this article - as Wildlife Park managers and trustees sought to keep animals inside park boundaries while obscuring all evidence of their confinement. Concealing artifice through human engineering was essential if tourists were to have authentic experiences with nature. ${ }^{10}$

\footnotetext{
${ }^{9}$ Mitman, "When Nature was a Zoo"; On the name change, see Harold Fabian to Vanderbilt Webb, Wildlife Park Collection, Box 1, Series 1, Folder 1.

10 "Cost in Delivering and Capturing of Game Animals for Wildlife Park", undated, Wildlife Park Collection, Box 1, Series 1, Folder 1; Richard Winger
} 


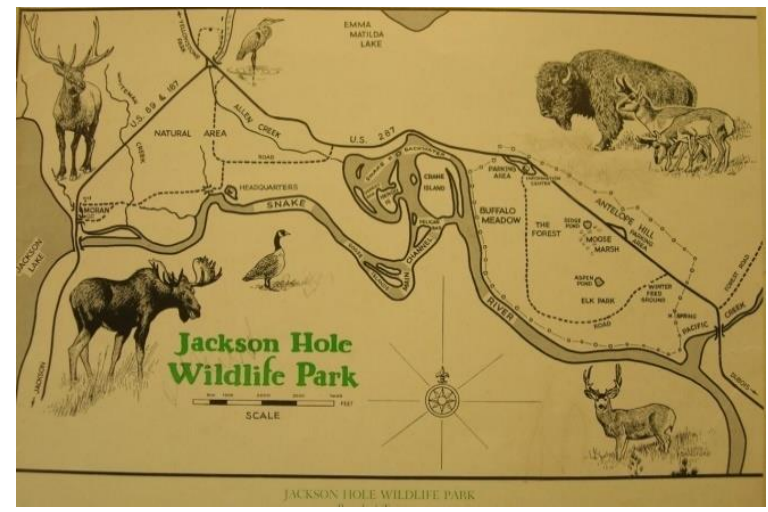

Figure. 3. Map of Jackson Hole Wildlife Park, available for visitors in 1948. Reprinted, by permission, from Grand Teton National Park: Jackson Hole Wildlife Park, Historic Records Collection.

Though there is little quantifiable evidence as to whether these tourists had an authentic encounter with nature, some visitor figures from 1947-1951 are available. At the end of 1951, one year before the JHWP closed, 275,000 people had visited, with the totals progressively increasing after $1947 .^{11}$

In addition to viewing wildlife (Figure 4), educational literature was available for browsing and purchase. Among the individual pamphlets available were those on moose, elk, deer, coyotes, buffalo, and other animals. Visitors could also purchase a set of slides on Yellowstone for $\$ 1.95$, or a booklet titled, "Exploring our National Parks and Monuments." They could even buy a "Jackson Hole Wildlife Park" collectible handkerchief should their visit inspire an emotional response, or if they simply sought souvenirs. Those who desired a more comprehensive overview of wildlife within the greater Jackson Hole ecosystem could purchase Fairfi eld Osborn's "Jackson Hole Wildlife Park" brochure. In addition to helping the curious traveler understand the wildlife within the enclosure, it also provided brief vignettes on the region's fish, birds, flora, and smaller mammals. The same visitor could also peruse a more in-depth pamphlet on the elk of the region, the research

to Laurance Rockefeller, 10 July 1946, Wildlife Park Collection, Box 1, Series 2, Folder 5; Mitman, "When Nature was a Zoo."

11 "Minutes of a Special Meeting of the Members and Board of Trustees of Jackson Hole Wildlife Park", 25 August 1951, in Wildlife Park Collection, Box 3, Series 2, folder 3.

${ }^{12}$ Unsigned to HF Schieman, 10 June 1953, James Simon to HF Schieman, 12 February 1953, HF Schieman to James Simon, 10 June 1953, above letters of which was provided by the foremost expert on the species in North America, Olaus Murie. Ironically, the average tourist reading this pamphlet (and having arrived by car) would be unaware of Murie's critique of roadside wildlife viewing. That same individual would not likely be conscious of how Murie and Osborn clashed over the role of tourism in conservation. Nonetheless, concerns over how humans encountered wildlife remained a source of tension amongst those who managed the Wildlife Park. $^{12}$

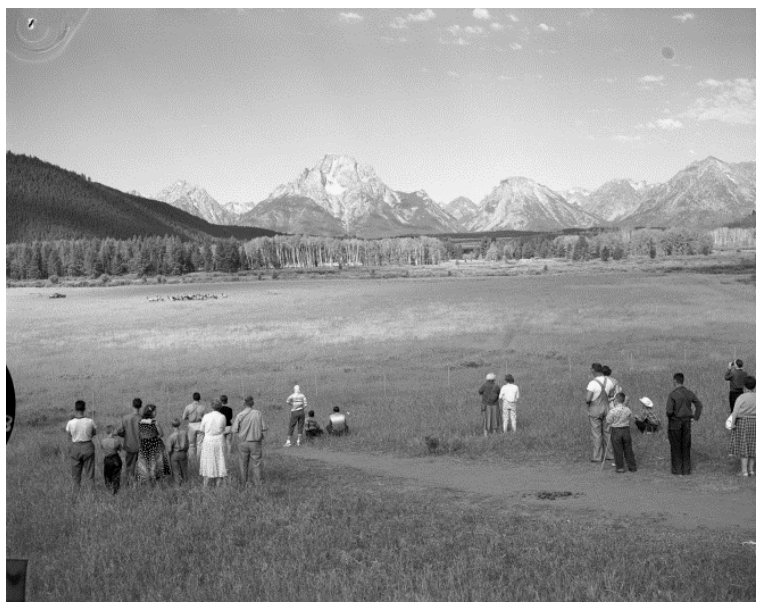

Figure 4. Tourists visit the Wildlife Park. Reprinted, by permission, from Grand Teton National Park: Jackson Hole Wildlife Park, Historic Records Collection.

Lists of animals brought into the Wildlife Park revealed that no big game predators were included. By the early 1920s, wolves in the region had been hunted almost to extinction. Coyotes maintained an active presence in the area, but their right to exist was contested since they preyed on the same animals desired by both tourists and hunters. ${ }^{13}$ For the employees of WDFG who managed the day-to-day operations of the Park, coyotes were alternately perceived of as nuisances to be kept out of the enclosed portion of the park, or vermin to be shot. In fact, records from 1947-1952 provide convincing evidence that deterring coyotes from entering the enclosure

in Wildlife Park Collection, Box 3, Series 3, Folder 15; Fairfield Osborn, Jackson Hole Wildlife Park, and The American Elk, or Wapiti, in AHC, University of Wyoming, "UW-National Park Research Center Records", Box 1.

${ }^{13}$ For a brief history of human perceptions of wolves and coyotes in the United States and attempts to eradicate them, see Donald Worster, Nature's Economy: A History of Ecological Ideas (New York: Cambridge Press, 1977). 
occupied large chunks of their time. Snow drifts piled up at the base of Park fences enabling coyotes to leap into the enclosure. On more than one occasion, coyotes killed resident deer. It was far more common however for these predators to be shot by WDFG. ${ }^{14}$

The same snow drifts that enabled coyotes to prey on deer also allowed wildlife to escape the enclosure. Soon after assuming management duties, park director James Simon gave up all pretense of keeping moose and elk within the enclosure. The long legs of moose and the athleticism of elk, combined with deep and encrusted snow demonstrated just how permeable were JHWP borders. ${ }^{15}$

Elk presented issues which were both specific to the JHWP and representative of broader complexities within Jackson Hole. The elk herd in Jackson Hole was one of the largest in the world. Prior to homesteading in the late nineteenth- and early twentieth-century, the herd migrated south to lower elevations for the winter. However, increased human population and property fences blocked migration patterns. Consequently, an Elk Refuge was established in Jackson Hole in 1912 which served primarily to provide winter feed in the harsh Jackson Hole climate. That extra feed enabled the region to both maintain an artificially high carrying capacity of elk, and provide more abundant elk without challenging the property rights of local landowners. ${ }^{16}$

In some ways then the Wildlife Park supported the mission of WDFG. By feeding elk in the winter, the JHWP provided additional winter habitat for elk in the region. Though a small number of those elk remained protected in the enclosure throughout the year, the majority of elk came to the JHWP in the cold months and remained only for the available feed. During fall hunting season, they could often be found in the nearby Teton National Forest where they might become a trophy for a local sportsman, or for a visitor who had been enticed by the big game opportunities in Jackson Hole. Of course, both brands of sportsmen paid for Fish and Gameissued hunting permits. In addition, visiting hunters

14 “Feeding Reports, 1948-1949", AHC, University of Wyoming, "UW-National Park Research Center Records", Box 1, "Department of Fish and Game".

15 James Simon to Members of the Jackson Hole Wildlife Park Board of Directors and Advisory Board Members, 15 April 1952, in Wildlife Park Collection, Box 5, Series 11, Folder 1.

${ }^{16}$ For an excellent general history of Jackson Hole which includes chapters on elk, conservation, and tourism see John Daugherty, A Place Called Jackson Hole: The Historic Resource Study of Grand Teton National Park (Moose, WY: National Park Service, 1999). would especially benefit local and state economies in their pursuits. Moreover, WDFG officials presumed that some of those who gawked at elk in the JHWP in the summer might be enticed to pay large sums of money to shoot at them in the fall. This was the perspective held by Lester Bagley and Carl Jorgenson, WDFG officials, and vote-wielding trustees of the JHWP. It was a position shared by Wyoming governors Lester Hunt and Frank Barrett, both of whom were non-voting trustees of the JHWP. ${ }^{17}$

Such views often placed Bagley and Jorgenson in conflict with the other trustees. One issue that demonstrated this conflict was the Jackson Hole National Monument (JHNM). Wyoming Department of Fish and Game, Governor Hunt, and many Jackson Hole locals opposed the JHNM since its inception in 1943 because it prohibited hunting within its boundaries. $^{18}$ This put them at odds with JHWP President Laurance Rockefeller whose family fortune made both the Monument and the Wildlife Park possible. Trustees Harold Fabian and Kenneth Chorley had worked as Rockefeller's representatives since the 1930s. They could be counted on to side with Laurance. Finally, fellow trustee Fairfield Osborn worked closely with Rockefeller to conceive of the JHWP in 1945, and thus held similar views on its purpose. Taken as a whole, this group sought to bring tourists into the Park, but gave only lukewarm support to hunting, and was far more willing to trust the National Park Service than either locals or the WDFG.

Between 1947 and 1952, these philosophical rifts were revealed on several occasions. As a sponsor of the JHWP, the state of Wyoming offered an annual appropriation that hovered around $\$ 5,000$. Hoping to have greater control in day-to-day management operations, they argued that half of their allotment should be used to pay the salary of JHWP director James Simon. The majority of the trustees refused this concession, believing that it would limit some of their autonomy in JHWP operations. In 1951, Senator Lester Hunt (former Wyoming governor) complained of the "lack of wild animals on public display," and

17 Richard Winger to Laurance Rockefeller, 10 July 1946, in Wildlife Park Collection, Box 1, Series 2, Folder 1.

${ }^{18}$ The prohibition on hunting could be rescinded once annually when the NPS, in collaboration with WDFG determined if the elk numbers had exceeded carrying capacity. If so, they would issue temporary hunting permits. This was the subject of annual controversy since the WDFG generally supported an annual hunt on the Monument, while the NPS often disagreed and was loathe to issue permits. 
that "Fairfield Osborn was more interested in the research work than he was in the exhibition of animals." He thought that the original mission of the JHWP (apparently to display large game animals to a desirous public) was not being prosecuted. WDFG and other officials of the state also clashed with the JHWP over cattleguards, fences, and the roads that ran through the Wildlife Park. Consequently, it came as no great surprise when the state of Wyoming pulled its funding for the JHWP in 1952, the last full year of the Wildlife Park's existence. ${ }^{19}$

Perhaps the most significant reason why the state of Wyoming dropped its support was related to an event only indirectly connected to the JHWP. On December 16, 1949, finally confident that their lands would become part of a national park, Laurance and John D. Rockefeller Jr. transferred over 32,000 acres of land to the federal government, including those acres comprising the Wildlife Park. The following September, Congress added the Jackson Hole National Monument and the original Grand Teton National Park to those acres to form an expanded national park. ${ }^{20}$ Though the JHWP continued to operate under a renewable ten-year lease signed by the NPS and Wildlife Park trustees in 1950, it was becoming clear that management of the Wildlife Park would require close cooperation with the National Park Service. Given the long history of animosity between the state of Wyoming and the NPS, there was little chance for successful collaboration.

On August 23, 1952, the JHWP trustees listened intently as Fairfield Osborn read a letter penned by Laurance Rockefeller which requested that the trustees effectively end their oversight of the Wildlife Park and transfer its operations to Grand Teton National Park. For Rockefeller, this was not a defeat, but a long-awaited triumph. In 1927, when his father had begun purchasing land in Jackson Hole, his goal was to eventually turn that land over to the federal government for the creation of a national park, a park that would include the lands on which the JHWP sat.

${ }^{19}$ For examples of these philosophical rifts, see Wyoming Fish and Game Commission to Fairfield Osborn (undated), in Wildlife Park Collection, Box 1, Series 2, Folder 2, James Simon to Fairfield Osborn, 23 January 1949, Wildlife Park Collection, Box 4, and Kenneth Chorley to Harold Fabian, 17 July 1951, in Wildlife Park Collection, Box 4, Series 4, Folder 1.

${ }^{20}$ Daugherty, 320-327; Righter, 126-141.

21 Comments from Laurance Rockefeller in "Minutes of a Special Meeting of the members, Board of Trustees, and Advisory Board of Jackson Hole Wildlife Park" 23 August 1952, in Wildlife Park Collection, Box 5, Series 14, Folder 2.
Among voting trustees, there was little discussion and no hint of disagreement with Rockefeller's stated wishes. $^{21}$

Amongst those present at that meeting, there were only two dissenting voices: Struthers Burt and Charles Cornell Moore. Both men had at one time been dude ranchers in the area. In fact Burt played a prominent role in attracting the Rockefellers to Jackson Hole in the 1920s. Though both Burt and Moore hoped to see Jackson Hole preserved from development, they did not wish to see its management passed completely out of local hands. In a letter to Rockefeller, Moore reminded Laurance that federal control had been a "thorn in the side of those who would conserve Jackson Hole." He also argued that turning over the Wildlife Park to the NPS “just makes another Park which in all probability will be under the charge of a ranger with no particular interest." For Rockefeller, that NPS ranger represented the triumph of conservation in Jackson Hole. For Burt and Moore, Park Service control of the Wildlife Park signified that Jackson Hole locals no longer possessed a voice in the conservation of the lands on which they lived. ${ }^{22}$

Burt and Moore's fears that NPS control of the Wildlife Park would lead to its demise were wellfounded. On July 1, 1953 the Park Service discontinued the JHWP, tore down its fences, and released the animals which remained (Figure 5). Their decision was largely due to its policy of not confining or feeding wildlife within the boundaries of a national park. ${ }^{23}$ However, the research component of the JHWP carried on. Initially, the Jackson Hole Research Station was to be administered by the New York Zoological Society. This made logical sense because Fairfield Osborn was its president, and the Society possessed the financial resources and scientific expertise to support ongoing research in Grand Teton. Eventually, the New York Zoological Society discontinued its affiliation with the Research Station, and management of its programs and facilities became a joint project of the University of Wyoming and the

${ }^{22}$ Comments from Laurance Rockefeller; Charles Cornell Moore to Laurance Rockefeller, 12 September 1952, in Wildlife Park Collection, Box 5, Series 14, Box 2.

${ }^{23}$ That policy was instituted in 1942. For more on this, see Marguerite Shaffer, "Performing Bears and Packaged Wilderness: Reframing the History of National Parks," in Cities and Nature in the American West (Reno: University of Nevada Press, 2010), and Sellars, Preserving Nature in the National Parks.

${ }^{24}$ Kenneth Diem, “The Research Station's Place in History," 1978, unpublished typescript in Diem collection at American Heritage Center. 
National Park Service. In an ironic twist which would have been appreciated by both Burt and Moore, the Research Station was moved in 1978 to the location of a private residence, the AMK, on the shores of Jackson Lake. It resides there today. ${ }^{24}$

Today, tourists entering Grand Teton from the east pass through the site of the former Wildlife Park. One of the roadside pullouts occupies the site where formerly there was a viewing platform and information on large game animals to be found in the Park. That platform and all other human constructions have been removed. A traveler will also pass within full view of the gentle hillside where Laurance Rockefeller delivered his invocation speech in 1948. Yet there is no evidence of the platform on which he spoke, or the benches cut into the terraced hillside where an expectant audience listened. One can even drive into the former Wildlife Park all the way to the banks of the Snake River at Oxbow Bend where a sign commemorates a historical wagon trail that passed through there in the nineteenth century. Yet the placard makes no mention that the same spot where travelers once forded the river was also a site managed for viewing large ungulates. It should then come as no surprise that there remains no visual evidence of animal enclosures or winter feeding operations.

This seems unfortunate and perhaps even a bit disingenuous. Grand Teton is a park where the human past is emphasized. Tourists can visit the sites of former cattle ranches and dude ranches (some of which are being restored). There are sites which commemorate movies filmed within park boundaries. Grand Teton even contains entire neighborhoods of non-NPS employees within its boundaries. And, one of the crown jewels of the park is the Rockefeller Preserve, the brainchild of Laurance Rockefeller, where both natural and constructed evidence of his philanthropy abounds. Yet none of the interpretive displays hint at his role in the Wildlife Park. As the history of the Jackson Hole Wildlife Park demonstrates, tourism, conservation, science, education, and the viewing of wildlife have not always operated in harmony. Nonetheless, managing the tension between them remains central to the daily operation of national parks. It is no less true today than on that fateful day in 1948 when Laurance Rockefeller opened the Wildlife Park.

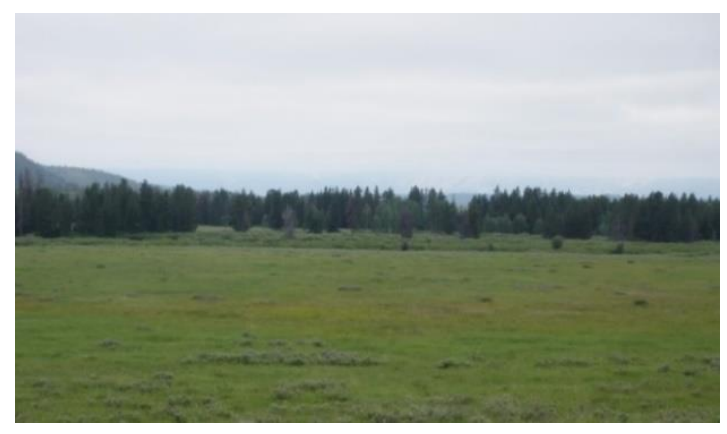

Figure 5. View of the meadow where the Wildlife Park once existed. Photo was taken from the spot where visitors sat in 1948 to hear Laurance Rockefeller speak at the opening ceremony. Photo by author

\section{$\uparrow \quad$ ACKNOWLEDGEMENTS}

I would like to thank Susanne McDonald of the Laurance Rockefeller Preserve and Alice Hart at the Grand Teton Park Archives for their help in locating resources. Robert Righter's thoughts were helpful in putting the Wildlife Park into historic perspective. Finally, I am grateful for the financial support of the University of Wyoming and the National Park Service which made the research and writing of this article possible. 